\title{
Environmental drivers of carbon and nitrogen isotopic signatures in peatland vascular plants along an altitude gradient
}

\author{
Konstantin Gavazov $^{1,2} \cdot$ Frank Hagedorn $^{3} \cdot$ Alexandre Buttler $^{1,2,4} \cdot$ Rolf Siegwolf $^{5}$. \\ Luca Bragazza ${ }^{1,2,6}$
}

Received: 27 May 2015 / Accepted: 14 September 2015 / Published online: 3 October 2015

(C) Springer-Verlag Berlin Heidelberg 2015

\begin{abstract}
Peatlands are important sinks of atmospheric carbon $(\mathrm{C})$ that, in response to climate warming, are undergoing dynamic vegetation succession. Here we examined the hypothesis that the uptake of nutrients by different plant growth forms (PGFs) is one key mechanism driving changes in species abundance in peatlands. Along an altitude gradient representing a natural climate experiment, we compared the variability of the stable $\mathrm{C}$ isotope composition $\left(\delta^{13} \mathrm{C}\right)$ and stable nitrogen $(\mathrm{N})$ isotope composition $\left(\delta^{15} \mathrm{~N}\right)$ in current-year leaves of two major PGFs, i.e. ericoids and graminoids. The climate gradient was associated with a gradient of vascular plant cover, which was parallelled by different concentrations of organic and inorganic $\mathrm{N}$ as well as the fungal/bacterial ratio in peat. In both
\end{abstract}

Communicated by Allan T. G. Green.

Luca Bragazza

luca.bragazza@wsl.ch

1 Swiss Federal Institute for Forest, Snow and Landscape Research, WSL Site Lausanne, Station 2, 1015 Lausanne, Switzerland

2 Ecole Polytechnique Fédérale de Lausanne EPFL, School of Architecture, Civil and Environmental Engineering ENAC, Laboratory of Ecological Systems ECOS, Station 2, 1015 Lausanne, Switzerland

3 Swiss Federal Institute for Forest, Snow and Landscape Research, WSL Site Birmensdorf, 8903 Birmensdorf, Switzerland

4 Laboratoire de Chrono-Environnement, UMR CNRS 6249, UFR des Sciences et Techniques, Université de FrancheComté, Besançon 25030, France

5 Paul Scherrer Institute PSI, 5232 Villigen, Switzerland

6 Department of Life Science and Biotechnologies, University of Ferrara, Corso Ercole I d'Este 32, Ferrara 44121, Italy
PGFs the ${ }^{13} \mathrm{C}$ natural abundance showed a marginal spatial decrease with altitude and a temporal decrease with progression of the growing season. Our data highlight a primary physical control of foliar $\delta^{13} \mathrm{C}$ signature, which is independent from the PGFs. Natural abundance of foliar ${ }^{15} \mathrm{~N}$ did not show any seasonal pattern and only in the ericoids showed depletion at lower elevation. This decreasing $\delta^{15} \mathrm{~N}$ pattern was primarily controlled by the higher relative availability of organic versus inorganic $\mathrm{N}$ and, only for the ericoids, by an increased proportion of fungi to bacteria in soil. Our space-for-time approach demonstrates that a change in abundance of PGFs is associated with a different strategy of nutrient acquisition (i.e. transfer via mycorrhizal symbiosis versus direct fine-root uptake), which could likely promote observed and predicted dwarf shrub expansion under climate change.

Keywords Ericoids · Graminoids · Leaf chemistry · Stable isotope ratio $\cdot$ Fungal/bacterial ratio $\cdot{ }^{13} \mathrm{C} \cdot{ }^{15} \mathrm{~N}$

\section{Introduction}

The stable isotopic composition of carbon (C) and nitrogen $(\mathrm{N})$ in plant tissues can provide insights into past and present environmental conditions as isotopic abundance integrates several biogeochemical processes (Dawson et al. 2002). Discrimination against the heavier ${ }^{13} \mathrm{C}$ isotope in plant leaves allows for the use of $\delta^{13} \mathrm{C}$ natural abundance as an indicator of the limiting conditions for photosynthesis (Körner et al. 1988; Farquhar et al. 1989). Similarly, the foliar $\delta^{15} \mathrm{~N}$ signature can reflect the hierarchical control of different environmental factors over $\mathrm{N}$ cycling (Robinson 2001). In particular, natural ${ }^{15} \mathrm{~N}$ abundance can provide information about the quality and quantity of available $\mathrm{N}$ as 
well as the strategy of $\mathrm{N}$ uptake by different plant species (Dawson et al. 2002; Amundson et al. 2003).

In nutrient-poor ecosystems such as ombrotrophic peatlands, isotopic composition of plant tissues can potentially reflect differences in acquisition strategies by different species or, more generally, by different plant growth forms (PGFs) (Asada et al. 2005; Aerts et al. 2009). PGFs typical of peatlands have been shown to be consistent in their function (Dorrepaal 2007), nutrient-acquisition strategies (Nadelhoffer et al. 1996), and responses to climate change (Elmendorf et al. 2012). Two of the most abundant PGFs in peatlands are ericoids, which include species belonging to the Ericaceae family, and graminoids which include species of the Cyperaceae and Poaceae families. The two PGFs have different strategies of nutrient acquisition, with ericoids being associated with ericoid mycorrhiza, while graminoids take up nutrients via their fine roots without fungal symbiosis or via associated arbuscular mycorrhizae (Hobbie and Högberg 2012; van der Heijden et al. 2015). In light of the expected vegetation dynamics in peatlands due to climate warming, vascular plants, in particular ericoids, are expected to become more abundant (Breeuwer et al. 2009; Bragazza et al. 2013). However, it still remains uncertain to what extent these changes in PGFs by climate warming are co-driven by changes in nutrient cycling and availability. It is essential to understand whether different PGFs can gain a competitive advantage for nutrient acquisition and whether this relates to belowground feedbacks via shifts in soil microbial community structure and soilavailable nutrients.

In this study, we take advantage of an established altitude gradient of ombrotrophic peatlands characterised by decreasing vascular plant abundance with increasing altitude (Bragazza et al. 2015). The natural gradient of temperature and precipitation selected here is consistent with the future climate scenarios for Switzerland (Frei 2007), whereas the change of vascular plant abundance reflects the vegetation dynamics reported by vegetation monitoring programs (Klaus 2007). Our aim is to determine to what extent abiotic versus biotic drivers control the variation in the natural abundance of foliar ${ }^{13} \mathrm{C}$ and ${ }^{15} \mathrm{~N}$ in two PGFs (i.e. graminoids and ericoids) in relation to climate (altitude), phenology (season), nutrient availability [ratio of exchangeable organic (ON) to inorganic $\mathrm{N}$ (IN)] and soil microbial community structure (fungal to bacterial biomass ratio; $\mathrm{F} / \mathrm{R}$ ratio). We want to address these main questions:

1. To what extent do the PGFs differ, on a temporal and spatial scale, in their $\mathrm{C}$ and $\mathrm{N}$ content and associated isotopic signature?

2. Can the natural abundance of stable $\mathrm{N}$ isotope provide information on the underlying $\mathrm{N}$ acquisition mechanisms for the two PGFs?

\section{Materials and methods}

\section{Study sites}

We selected a representative set of ombrotrophic peatlands, i.e. bogs, in Switzerland along an altitude gradient (Table 1). The studied peatlands shared a similar $\mathrm{pH}$ (range 4.3-4.8) and plant species composition, which was primarily dominated by Sphagnum magellanicum, Sphagnum

Table 1 Characterization of the study sites

\begin{tabular}{|c|c|c|c|c|}
\hline & Lörmoos & Praz Rodet & Sortel & Hochrajen \\
\hline Altitude (m a.s.1.) & 584 & 1035 & 1406 & 1885 \\
\hline Latitude and longitude & $46^{\circ} 58^{\prime} \mathrm{N}, 7^{\circ} 24^{\prime} \mathrm{E}$ & $46^{\circ} 33^{\prime} \mathrm{N}, 6^{\circ} 10^{\prime} \mathrm{E}$ & $46^{\circ} 44^{\prime} \mathrm{N}, 7^{\circ} 22 \mathrm{E}$ & $46^{\circ} 36^{\prime} \mathrm{N}, 7^{\circ} 58^{\prime} \mathrm{E}$ \\
\hline Mean annual temperature $\left({ }^{\circ} \mathrm{C}\right)$ & 8.4 & 5.9 & 3.9 & 1.3 \\
\hline Mean annual precipitation (mm) & 1030 & 1274 & 1346 & 1427 \\
\hline Aboveground plant biomass $\left(\mathrm{g} \mathrm{m}^{-2}\right)$ & $270 \pm 37$ & $160 \pm 21$ & $154 \pm 26$ & $74 \pm 7$ \\
\hline \multicolumn{5}{|l|}{ Graminoids } \\
\hline Eriophorum vaginatum & $\times$ & $x$ & $\times$ & $\times$ \\
\hline Rhynchospora alba & $\times$ & & & \\
\hline Trichophorum cespitosum & & $x$ & $\times$ & $x$ \\
\hline \multicolumn{5}{|l|}{ Ericoids } \\
\hline Andromeda polifolia & & $x$ & $x$ & \\
\hline Calluna vulgaris & $x$ & $x$ & $x$ & $\times$ \\
\hline Vaccinium microcarpum & $\times$ & & & \\
\hline Vaccinium uliginosum & & & & $\times$ \\
\hline
\end{tabular}

Plant species' presence (cross) in each peatland for each of the two plant growth forms, i.e. graminoids and ericoids, is also reported. Aboveground plant biomass is the mean $( \pm 1 \mathrm{SE})$ of five replicates for each site 
capillifolium, and Sphagnum fallax in the moss layer, and by Eriophorum vaginatum, Calluna vulgaris, Vaccinium oxycoccus, Vaccinium uliginosum, and Vaccinium myrtillus in the vascular plant layer (Bragazza et al. 2013). The mean annual peat temperature at a depth between 5 and $10 \mathrm{~cm}$ decreased by $0.4{ }^{\circ} \mathrm{C} 100 \mathrm{~m}^{-1}$ altitude, whereas the peat water content increased by $0.2 \% 100 \mathrm{~m}^{-1}$ of altitude (Bragazza et al. 2013). Such an altitude gradient within a confined geographical region can be conceived of as a natural climate experiment where ecosystem processes can be primarily attributed to variation in temperature and precipitation (Körner 2007).

\section{Sampling design and chemical analysis}

Three vascular plant species representative of graminoids, i.e. E. vaginatum, Rhynchospora alba, and Trichophorum cespitosum, and four species representative of the ericoids, i.e. Andromeda polifolia, C. vulgaris, Vaccinium microcarpum and V. uliginosum, were considered in this study (the presence of each plant species along the altitude gradient is described in Table 1).

Following a standard protocol (Cornelissen et al. 2003), current-year leaves from at least ten representative plants of each species were collected in each peatland during the period late April-early October 2010 on five sampling dates. For each species, the leaf samples were pooled together in a bulk sample, dried at $40{ }^{\circ} \mathrm{C}$ for $48 \mathrm{~h}$, homogenised in a ball mill, and analysed for their $\mathrm{C}$ and $\mathrm{N}$ concentration and isotopic abundance in an elemental analyser coupled online with an isotope ratio mass spectrometer (DELTA V Advantage; Thermo Scientific, Germany). C and $\mathrm{N}$ isotopic abundance is expressed, respectively, as $\delta^{13} \mathrm{C}$ and $\delta^{15} \mathrm{~N}$, and was calculated as follows: $\delta(\% o)=\left[\left(R_{\text {sample }} /\right.\right.$ $\left.\left.R_{\text {standard }}\right)-1\right)$ ], where $R$ is the ${ }^{13} \mathrm{C} /{ }^{12} \mathrm{C}$ or the ${ }^{15} \mathrm{~N} /{ }^{14} \mathrm{~N}$ ratio of the sample and the correspondent standard, i.e. Vienna Pee Dee belemnite for $\mathrm{C}$ and atmospheric $\mathrm{N}_{2}$ for $\mathrm{N}$. The SD of replicates was always better than $0.2 \%$.

The same day of leaf sampling, three peat samples were collected at each site by means of a knife at a depth between 5 and $15 \mathrm{~cm}$, in order to exclude the upper living portion of Sphagnum plants, but to include the peat depth where the highest fine-root production is expected (Bragazza et al. 2013). Total exchangeable $\mathrm{N}$ and exchangeable ammonium $\left(\mathrm{NH}_{4}{ }^{+}\right)$and nitrate $\left(\mathrm{NO}_{3}{ }^{-}\right)$were determined after extraction of peat samples with $0.5 \mathrm{M}$ potassium sulphate and Milli-Q water (for nitrate only). The sum of exchangeable $\mathrm{NH}_{4}{ }^{+}$and $\mathrm{NO}_{3}{ }^{-}$concentrations corresponded to exchangeable peat IN and the difference between total $\mathrm{N}$ and IN concentration corresponded to the exchangeable organic $\mathrm{N}$ $(\mathrm{ON})$. Before analysis, all solutions were filtered through a $0.45-\mu \mathrm{m}$ glass fibre filter. Total exchangeable $\mathrm{N}$ was analysed by combustion using a Shimadzu analyser (TOC-V CPHCTNM-1), whereas exchangeable $\mathrm{NH}_{4}{ }^{+}$and $\mathrm{NO}_{3}{ }^{-}$ (IN) were determined colorimetrically using a continuous-flow autoanalyser (FlowSys; Systea, Rome). The F/B ratio in peat samples was determined by the phospholipidderived fatty acid technique. Lipids were extracted from lyophilised fresh peat with a solution of chloroform, methanol and potassium phosphate buffer and then separated into neutral, glycol-, and phospholipids on silica solid phase extraction cartridges. The phospholipids were then transesterified in fatty acid methyl esters and detected by gas chromatography (Varian CP3800, USA). The ratio between the fungal biomarker $(18: 2 \omega 6)$ and the sum of bacterial

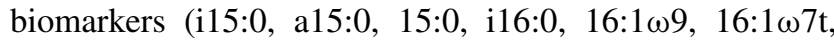
i17:0, a17:0, 17:0, cy17:0, 18:1 $1 \omega 7$ ) was used as a F/B ratio (Jaatinen et al. 2007).

\section{Statistical analysis}

For all statistical analyses, data of leaf chemical composition of each plant species were grouped together according to PGF, i.e. graminoids and ericoids. Due to the change in species' presence along the altitude gradient (see Table 1), we performed a sensitivity analysis by replacing sequentially in each of the two PGFs the local species with a species from the respective PGF type which occurred in all of the four peatlands (i.e. C. vulgaris for ericoids and E. vaginatum for graminoids). The results of this sensitivity analysis confirmed the uniform and consistent pattern among the studied plant species within both PGF types.

We used repeated-measures ANOVA to detect the effects of PGFs (categorical variable), altitude (continuous variable) and sampling date (continuous variable) on plant leaf chemical composition. We applied a linear mixed-effects model, using a restricted maximum likelihood procedure, with sampling date as a random factor. A similar model was applied to test the relationship between foliar $\delta^{15} \mathrm{~N}$ and peat $\mathrm{F} / \mathrm{B}$ ratio, as well as between foliar $\delta^{15} \mathrm{~N}$ and peat exchangeable ON/IN ratio, in order to account for the spatial and temporal structure of our data. As a general rule (Green and Tukey 1960), non-significant interaction terms with $F$-values $<2.0$ were pooled with the error term. To elucidate significant interactions with PGF, the effects of altitude and sampling date were furthermore tested within each PGF type using the same model structure (Engqvist 2005). Data were visually inspected for normality and homoscedasticity of variance prior to analysis. All final models were checked for homogeneity of the residuals. Analysis was performed with R 3.1.1 (R Core Team 2014) using the nlme package (Pinheiro et al. 2014). 


\section{Results}

\section{Foliar $\mathbf{C}$ and $\mathbf{N}$ concentration}

Mean $( \pm 1 \mathrm{SE})$ leaf $\mathrm{C}$ concentration was significantly greater $\left(F_{1,53}=173.6, P<0.001\right)$ in the ericoids $(48.04 \% \pm 0.31)$ than in the graminoids $(43.89 \% \pm 0.22)$, with no distinct pattern in relation to altitude or sampling date for either of the PGFs (Fig. 1a, b). Mean ( \pm 1 SE) leaf $\mathrm{N}$ concentration did not differ between PGFs ( $1.43 \% \pm 0.11$ for graminoids and $1.46 \% \pm 0.14$ for ericoids) and it increased significantly $\left(F_{1}\right.$, ${ }_{16}=40.9, P<0.001$ ) with altitude in both the PGFs (Fig. 2a, b). In addition, from April to October, there was a significant seasonal decline of $\mathrm{N}$ concentration $\left(F_{1,16}=76.2, P<0.001\right)$ in the leaves of ericoids and, particularly, in graminoids in all the peatlands. In the graminoids, during the entire season, the mean $\mathrm{C} / \mathrm{N}$ ratio was $40.4,42.8,35.5$ and 32.6 from the lowest (Lörmoos) to the highest (Hochrajen) altitude site. Similarly, in the ericoids, the mean $\mathrm{C} / \mathrm{N}$ ratio was 40.5, 42.6, 35.6, and 26.9 along the same gradient. Overall, due to the stable
C concentration, the leaf $\mathrm{C} / \mathrm{N}$ ratio of both PGFs was highly collinear with $\mathrm{N}$ content $\left(R^{2}=0.87, P<0.001\right)$.

\section{Foliar ${ }^{13} \mathrm{C}$ and ${ }^{15} \mathrm{~N}$ isotopic signatures}

Mean $( \pm 1 \mathrm{SE})$ leaf $\delta^{13} \mathrm{C}$ was significantly less negative $\left(F_{1}\right.$, $\left.{ }_{53}=125.0, P<0.001\right)$ in the graminoids $(-26.85 \%$ \pm 0.16$)$ than in the ericoids $(-28.83 \% \circ \pm 0.23)$, regardless of altitude or sampling date (Fig. 1c, d). For both the PGFs the $\delta^{13} \mathrm{C}$ showed a marginal decrease with altitude $\left(F_{1,16}=3.4\right.$, $P=0.083$ ), whereas it was significantly greater at the beginning of the growing season both for the graminoids $\left(F_{1}\right.$, $\left.{ }_{17}=4.9, P=0.042\right)$ and the ericoids $\left(F_{1,17}=4.7, P=0.045\right)$. Foliar $\delta^{15} \mathrm{~N}$ in the graminoids $(-3.96 \% 0 \pm 0.22)$ was significantly less negative $\left(F_{1,51}=699.2, P<0.001\right)$ than in the ericoids $(-10.92 \% \circ \pm 0.50)$ (Fig. 2c, d), and only in the case of ericoids did it significantly increase along the altitude gradient $\left(F_{1,17}=11.1, P=0.004\right)$. This was reflected by a significant interaction between PGF and altitude $\left(F_{1,51}=14.0\right.$, $P<0.001)$. No seasonal pattern in foliar $\delta^{15} \mathrm{~N}$ was observed for either PGFs.

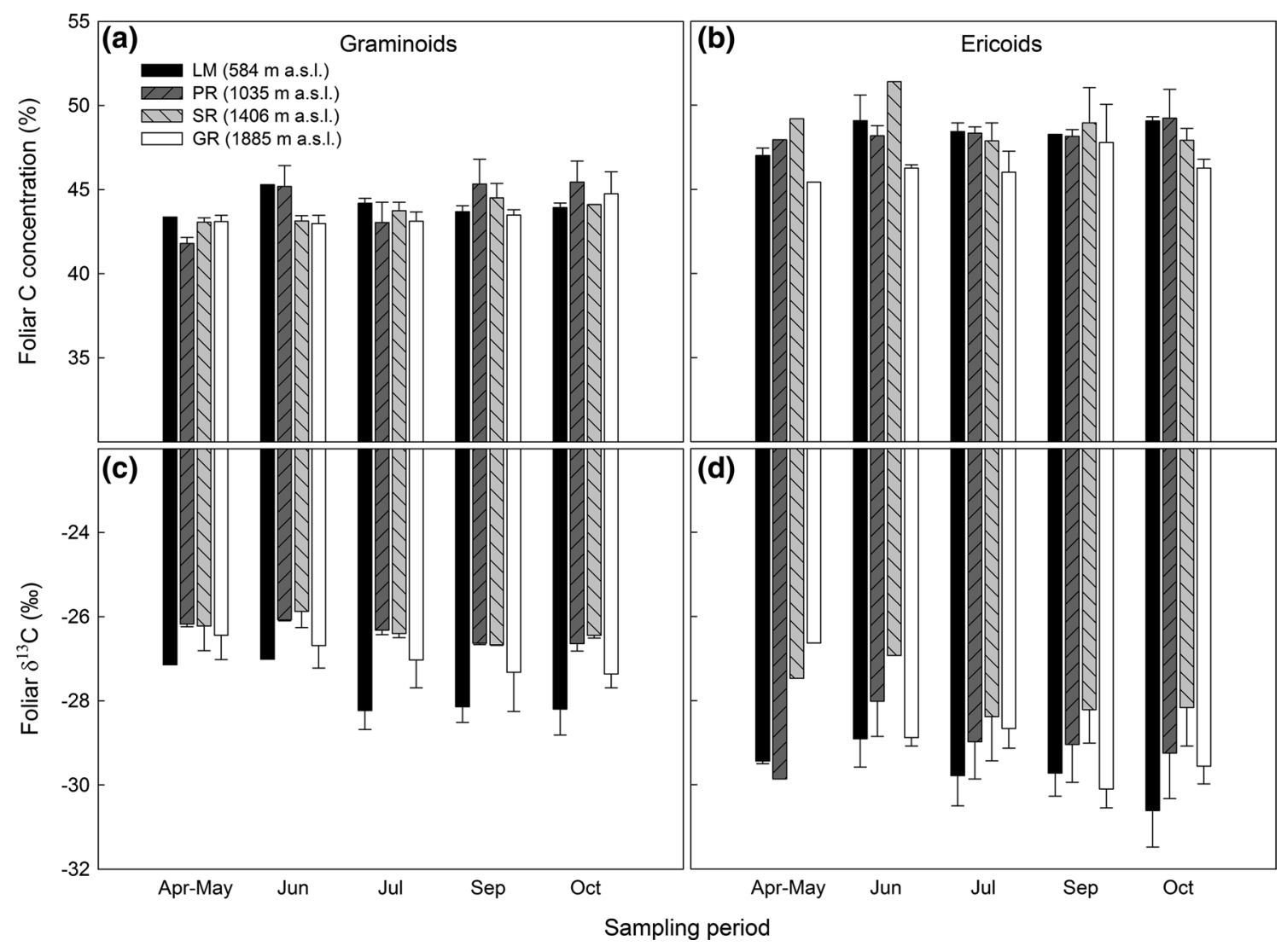

Fig. 1 Foliar carbon (C) concentration and $\delta^{13} \mathrm{C}$ isotopic signature in graminoids $(\mathbf{a}, \mathbf{c})$ and ericoids $(\mathbf{b}, \mathbf{d})$ in the four studied peatlands [Lörmoos $(L M)$, Praz Rodet $(P R)$, Sortel $(S R)$, and Hochrajen $(G R)$ ] at different altitudes and at five sampling periods between late April and early October 2010. Values are seasonal means $\pm 1 \mathrm{SE}(n=2)$ 


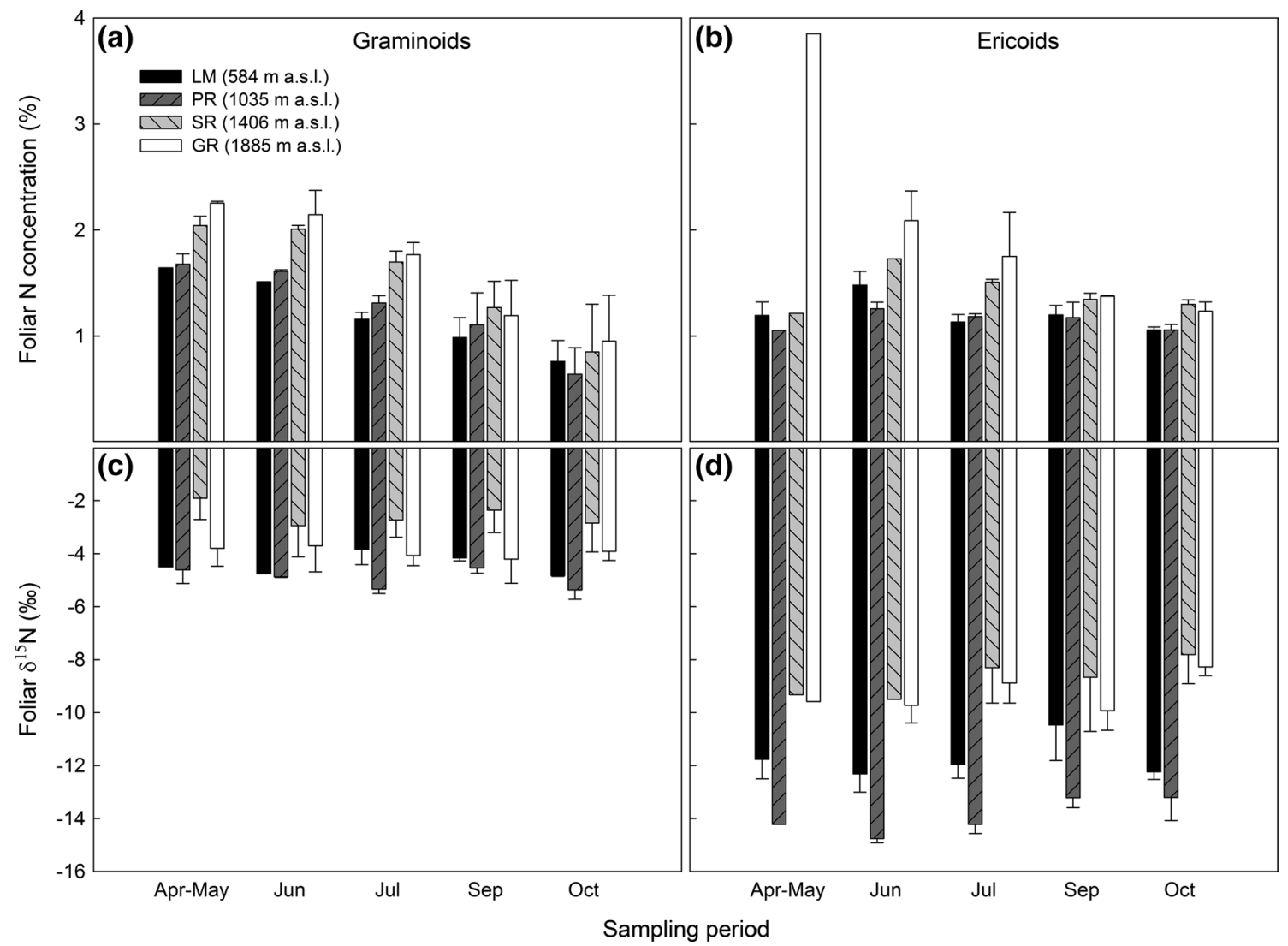

Fig. 2 Foliar nitrogen $(\mathrm{N})$ concentration and $\delta^{15} \mathrm{~N}$ isotopic signature in graminoids $(\mathbf{a}, \mathbf{c})$ and ericoids $(\mathbf{b}, \mathbf{d})$ in the four studied peatlands (LM, PR, SR, and GR) at different altitudes and at five sampling peri-

The $\delta^{15} \mathrm{~N}$ of graminoids was independent $\left(F_{1,18}=2.6\right.$, $P=0.126)$ from the $\mathrm{F} / \mathrm{B}$ ratio of peat soil, whereas the $\delta^{15} \mathrm{~N}$ of ericoids was significantly $\left(F_{1,18}=11.4, P=0.003\right)$ more negative with an increasing F/B ratio (Fig. 3). This latter pattern was largely driven by the strong increase in the $\mathrm{F} / \mathrm{B}$ ratio with decreasing altitude $\left(F_{1,16}=40.9\right.$, $P<0.001)$. The ON/IN ratio in the peat soil was negatively correlated with the isotopic signature in both PGFs (Fig. 4). Indeed, $\delta^{15} \mathrm{~N}$ declined with an increasing ON/IN ratio in graminoids $\left(F_{1,18}=16.7, P<0.001\right)$ and ericoids $\left(F_{1,18}=9.5, P=0.006\right)$.

\section{Discussion}

\section{Spatial and temporal pattern of $\mathrm{C}$ and $\mathrm{N}$ concentration in plant leaves}

In this study, graminoids show significantly lower foliar C concentrations than ericoids, in accordance with the lower fractions of lignin, tannins and structural carbohydrates in graminoids (Chapin and Shaver 1988; Diaz et al. 2004; ods between late April and early October 2010. Values are seasonal means $\pm 1 \mathrm{SE}(n=2)$. For abbreviations see Fig. 1

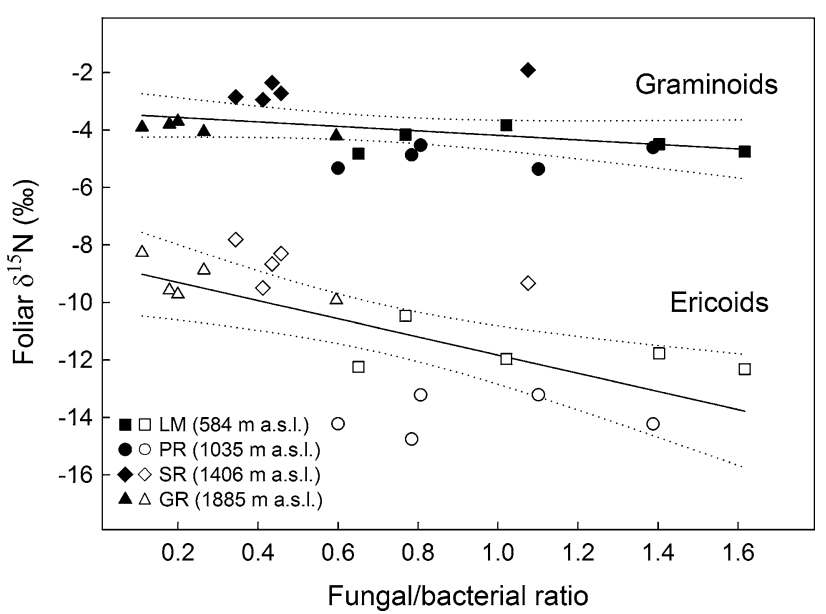

Fig. 3 Relationship between fungal/bacterial ratio in peat soil and foliar $\delta^{15} \mathrm{~N}$ signature of graminoids (filled symbols) and ericoids (empty symbols). The data represent the seasonal means (five sampling periods) for each peatland along the altitude gradient (different symbols). The regression for graminoids $\left(\delta^{15} \mathrm{~N}=-3.40-0.78 \times\right.$ fun$\mathrm{gal} / \mathrm{bacterial}$ ratio) is not significant, whereas that for ericoids $\left(\delta^{15} \mathrm{~N}=-8.67-3.16 \times\right.$ fungal/bacterial ratio $)$ is significant $(P<0.01$; see main text for details). Dotted lines represent $95 \%$ confidence intervals for each model. For abbreviations see Fig. 1 


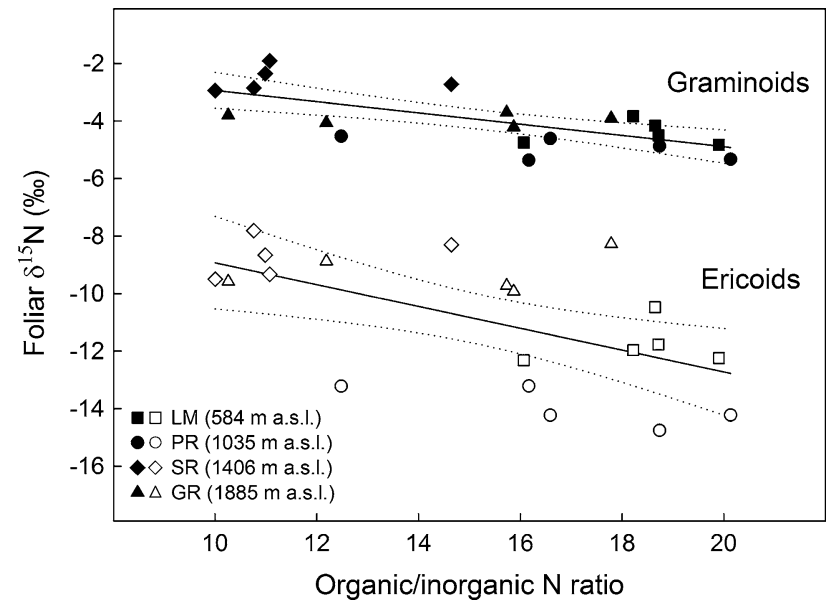

Fig. 4 Relationship between peat extractable organic/inorganic $\mathrm{N}$ ratio and foliar $\delta^{15} \mathrm{~N}$ signature of graminoids (filled symbols) and ericoids (empty symbols). The data represent the seasonal means (five sampling periods) for each peatland along the altitude gradient (different symbols). Both of the regressions for graminoids $\left(\delta^{15} \mathrm{~N}=-0.98-0.195 \times\right.$ organic/inorganic ratio $)$ and for ericoids $\left(\delta^{15} \mathrm{~N}=-5.131-0.380 \times\right.$ organic/inorganic ratio $)$ are significant $(P<0.01$; see main text for details). Dotted lines represent $95 \%$ confidence intervals for each model. For abbreviations see Fig. 1

Wright et al. 2005; Westoby and Wright 2006). As in Aerts et al. (1999), despite the dissimilarities in C concentration, the two PGFs do not differ in their mean $\mathrm{N}$ concentration, which translates into a smaller foliar $\mathrm{C} / \mathrm{N}$ ratio for the graminoids. Both PGFs have greater foliar $\mathrm{N}$ concentrations at higher altitude, which could be related to an improvement in leaf quality (e.g. decreasing $\mathrm{C} / \mathrm{N}$ ratio) with altitude as an adaptative mechanism for plant functioning, rather than to a lavish use of available nutrients (Körner 1989). Furthermore, the decrease of foliar $\mathrm{N}$ concentration during the plant growing season confirms a high resorption efficiency, in particular for graminoids (Aerts and Chapin 1999; van Heerwaarden et al. 2003; Vergutz et al. 2012).

\section{Spatial and temporal pattern of ${ }^{13} \mathrm{C}$ and ${ }^{15} \mathrm{~N}$ isotopic signatures in plant leaves}

Foliar $\delta^{13} \mathrm{C}$ follows a general pattern of decreased isotopic discrimination (i.e. ${ }^{13} \mathrm{C}$ enrichment) with increasing altitude, as observed at local and global scales in different plant species (Körner et al. 1988, 1991; Vitousek et al. 1990; Marshall and Zhang 1994; Hultine and Marshall 2000). In the light of the morphological differences between the studied PGFs, it is plausible that the marginal increase in ${ }^{13} \mathrm{C}$ abundance along the altitude gradient is primarily controlled by environmental physical conditions, in particular by the limited $\mathrm{CO}_{2}$ diffusion and the lower temperatures at higher altitude (Körner et al.1991; Terashima et al. 1995; Ménot and Burns 2001).
The more negative foliar $\delta^{13} \mathrm{C}$ of ericoids is in accordance with their $\mathrm{C}$ concentration and may reflect a greater lignin content being strongly depleted in ${ }^{13} \mathrm{C}$ (O'Leary 1981; Benner et al. 1987; Hobbie and Werner 2004). The leaf ${ }^{13} \mathrm{C}$ enrichment early in the growing season could be explained by the translocation of isotopically heavier nonstructural carbohydrates from the roots to the newly formed leaves (O'Leary 1981; Dawson et al. 2002; Cernusak et al. 2009; Werner and Gessler 2011).

The observed decrease of the F/B ratio with increasing altitude reflects both the sensitivity of fungi to anoxic soils (Jaatinen et al. 2007; Bragazza et al. 2015), as well as the decrease of ericoid biomass and its associated mycorrhizal fungi as expressed by the fungal phospholipid-derived fatty acid biomarker (Nilsson et al. 2005; Högberg et al. 2007; Andersen et al. 2013). The consistently lower $\delta^{15} \mathrm{~N}$ value of ericoid leaves compared to graminoids throughout the growing season and across all the studied peatlands is in line with the previously reported role of ericoid mycorrhizal symbiosis in controlling the ${ }^{15} \mathrm{~N}$ signature of host plants (Nadelhoffer et al. 1996; Evans 2001; Asada et al. 2005; Craine et al. 2009; Hobbie and Högberg 2012). Indeed, ${ }^{15} \mathrm{~N}$-depleted $\mathrm{N}$ is preferentially transferred to the host plants from the symbiotic fungi, resulting in an enrichment of ${ }^{15} \mathrm{~N}$ in the fungal mycelium and a depletion in the host plant (Emmerton et al. 2001; Robinson 2001; Hobbie and Colpaert 2003). Because the $\delta^{15} \mathrm{~N}$ of ericoid leaves decreases with increasing soil fungal abundance (increasing soil $\mathrm{F} / \mathrm{B}$ ratio), our data further support a previous indication that retention of ${ }^{15} \mathrm{~N}$-enriched $\mathrm{N}$ in the fungal mycelium is a primary mechanism controlling foliar ${ }^{15} \mathrm{~N}$ abundance (Hobbie and Colpaert 2003).

We also observed that for both PGFs the foliar ${ }^{15} \mathrm{~N}$ abundance decreases with increasing availability of exchangeable $\mathrm{ON}$ in the soil (Fig. 4). This result points to a role of the available $\mathrm{N}$ forms in controlling ${ }^{15} \mathrm{~N}$ through the relative concentration of $\mathrm{ON}$ compounds that are suggested to be depleted in ${ }^{15} \mathrm{~N}$ (Yano et al. 2009). At the same time, the fact that the $\delta^{15} \mathrm{~N}$ of graminoids decreases with increasing relative $\mathrm{ON}$ availability supports previous observations that in N-limited environments non-mycorrhizal plants, such as our study graminoids (Wang and Qiu 2006; Akhmetzhanova et al. 2012), can absorb low molecular weight organic N from the soil solution (Chapin et al. 1993; Emmerton et al. 2001).

In conclusion, the use of an altitude gradient, reflecting a gradient in both climate and vascular plant abundance, allowed us to relate the spatial and temporal variation of some main environmental drivers to the $\mathrm{C}$ and $\mathrm{N}$ isotopic signature of two dominant PGFs in peatlands. The increase in peat oxygenation with a warmer climate promotes the development of ericoids in parallel with the saprophytic and symbiotic fungal biomass, which ultimately controls 
the host plant ${ }^{15} \mathrm{~N}$ signature in the ericoids. In addition, the increase in ericoid abundance and associated release of polyphenols, which enhance ON availability (Bragazza et al. 2013), are ultimately reflected in the ${ }^{15} \mathrm{~N}$ signature of plant leaves due to a greater availability of ON forms. The observed strong association of the ericoid foliar $\delta^{15} \mathrm{~N}$ signature with both the increasing dominance of fungi over bacteria and greater availability of $\mathrm{ON}$ in peat soil has direct implications for plant-soil interactions. Our findings suggest that ericoids can shorten and tighten the $\mathrm{N}$ cycle through their mycorrhizal symbiosis, so reducing $\mathrm{N}$ losses and simultaneously gaining a competitive advantage over graminoids for $\mathrm{N}$ acquisition, ultimately promoting their expansion in a warmer climate.

Acknowledgments The Service des forêts, de la faune et de la nature (Canton de Vaud) and the Service de la promotion de la nature-Office de l'agriculture et de la nature (Canton de Berne) are acknowledged for giving permission to access the studied peatlands. Ursula Graf is also acknowledged for laboratory assistance. This study was financially supported by the Swiss National Science Foundation (project VeganPeat, Grant 205320-144024 to L. B.).

Author contribution statement L. B., F. H. and R. S. conceived and designed the study. L. B. and K. G. performed the field and laboratory activity. K. G. and L. B. analysed the data. K. G., L. B., F. H., R. S. and A. B. wrote the paper.

\section{Compliance with ethical standards}

Conflict of interest The authors declare that they have no conflict of interest.

\section{References}

Aerts R, Chapin FS (1999) The mineral nutrition of wild plants revisited: a re-evaluation of processes and patterns. In: Fitter AH, Raffaelli DG (eds) Advances in ecological research, vol 30. Elsevier, San Diego, pp 1-67

Aerts R, Verhoeven JT, Whigham DF (1999) Plant-mediated controls on nutrient cycling in temperate fens and bogs. Ecology 80:170-2181

Aerts R, Callaghan TV, Dorrepaal E, van Logtestijn RSP, Cornelissen JHC (2009) Seasonal climate manipulations result in speciesspecific changes in leaf nutrient levels and isotopic composition in a sub-arctic bog. Funct Ecol 23:680-688

Akhmetzhanova AA, Soudzilovskaia NA, Onipchenko VG, Cornwell WK, Agafonov VA, Selivanov IA, Cornelissen JHC (2012) A rediscovered treasure: mycorrhizal intensity database for 3000 vascular plant species across the former Soviet Union. Ecology 93:689-690

Amundson R, Austin AT, Schuur EAG, Yoo K, Matzek V, Kendall C, Uebersax A, Brenner D, Baisden WT (2003) Global patterns of the isotopic composition of soil and plant nitrogen. Glob Biogeochem Cycles 17:1031. doi:10.1029/2002GB001903

Andersen R, Chapman SJ, Artz RRE (2013) Microbial communities in natural and disturbed peatlands: a review. Soil Biol Biochem 57:979-994

Asada T, Warner BG, Aravena R (2005) Nitrogen isotope signature variability in plant species from open peatland. Aquat Bot 82:297-307
Benner R, Fogel ML, Sprague EK, Hodson RE (1987) Depletion of ${ }^{13} \mathrm{C}$ in lignin and its implications for stable carbon isotope studies. Nature 329:708-710

Bragazza L, Parisod J, Buttler A, Bardgett RD (2013) Biogeochemical plant-soil microbe feedback in response to climate warming in peatlands. Nat Clim Change 3:273-277

Bragazza L, Bardgett RD, Mitchell EAD, Buttler A (2015) Linking soil microbial communities to vascular plant abundance along a climate gradient. New Phytol 205:1175-1182

Breeuwer A, Robroek BJM, Limpens J, Heijmans MMPD, Schouten MGC, Berendse F (2009) Decreased summer water table depth affects peatland vegetation. Basic Appl Ecol 10:330-339

Cernusak LA, Tcherkez G, Keitel C, Cornwell WK, Santiago LS, Knohl A, Barbour MM, Williams DG, Reich PB, Ellsworth DS, Dawson TE, Griffiths HG, Farquhar GD, Wright IJ (2009) Why are non-photosynthetic tissues generally ${ }^{13} \mathrm{C}$ enriched compared with leaves in C3 plants? Review and synthesis of current hypotheses. Funct Plant Biol 36:199-2131

Chapin FS, Shaver GR (1988) Differences in carbon and nutrient fractions among arctic growth forms. Oecologia 77:506-514

Chapin FS, Moilanen L, Kielland K (1993) Preferential use of organic nitrogen for growth by a non-mycorrhizal arctic sedge. Nature 361:150-153

Cornelissen JHC, Lavorel S, Garnier E, Díaz S, Buchmann N, Gurvich DE, Reich PB, Ter Steege H, Morgan HD, Heijden MG, van der Pausas JG, Poorter H (2003) A handbook of protocols for standardised and easy measurement of plant functional traits worldwide. Aust J Bot 51:335-380

Craine JM, Elmore AJ, Aidar MPM, Bustamante M, Dawson TE, Hobbie E, Kahmen A, Mack MC, McLauchlan KK, Michelsen A, Nardoto GB, Pardo LH, Peñuelas J, Reich PB, Schuur EG, Stock WD, Templer PH, Virginia R, Welker JM, Wright IJ (2009) Global patterns of foliar nitrogen isotopes and their relationships with climate, mycorrhizal fungi, foliar nutrient concentrations, and nitrogen availability. New Phytol 183:980-992

Dawson TE, Mambelli S, Plamboeck AH, Templer PH, Tu KP (2002) Stable isotopes in plant ecology. Annu Rev Ecol Syst 33:507-559

Diaz S, Hodgson JG, Thompson K, Cabido M, Cornelissen JHC, Jalili A, Montserrat-Martí G, Grime JP, Zarrinkamar F, Asri Y, Band SR, Basconcelo S, Castro-Díez P, Funes G, Hamzehee B, Khoshnevi M, Pérez-Harguindeguy N, Pérez-Rontomé MC, Shirvany FA, Vendramini F, Yazdani S, Abbas-Azimi R, Bogaard A, Boustani S, Charles M, Dehghan M, de Torres-Espuny L, Falczuk V, Guerrero-Campo J, Hynd A, Jones G, Kowsary E, Kazemi-Saeed F, Maestro-Martínez M, Romo-Díez A, ShawS Siavash B, Villar-Salvador P, Zak MR (2004) The plant traits that drive ecosystems: evidence from three continents. J Veg Sci 15:295-304

Dorrepaal E (2007) Are plant growth-form-based classifications useful in predicting northern ecosystem carbon cycling feedbacks to climate change? J Ecol 95:1167-1180

Elmendorf SC, Henry GHR, Hollister RD, Björk RG, BoulangerLapointe N, Cooper EJ, Cornelissen JHC, Day TA, Dorrepaal E, Elumeeva TG, Gill M, Gould WA, Harte J, Hik DS, Hofgaard A, Johnson DR, Johnstone JF, Jónsdóttir IS, Jorgenson JC, Klanderud K, Klein JA, Koh S, Kudo G, Lara M, Lévesque E, Magnússon B, May JL, Mercado-Diaz JA, Michelsen A, Molau U, Myers-Smith IH, Oberbauer SF, Onipchenko VG, Rixen C, Martin Schmidt N, Shaver GR, Spasojevic MJ, Pórhallsdóttir PE, Tolvanen A, Troxler T, Tweedie CE, Villareal S, Wahren CH, Walker X, Webber PJ, Welker JM, Wipf S (2012) Plot-scale evidence of tundra vegetation change and links to recent summer warming. Nature Clim Ch 2:453-457

Emmerton KS, Callaghan TV, Jones HE, Leake JR, Michelsen A, Read DJ (2001) Assimilation and isotopic fractionation of 
nitrogen by mycorrhizal and nonmycorrhizal subarctic plants. New Phytol 151:513-524

Engqvist L (2005) The mistreatment of covariate interaction terms in linear model analyses of behavioural and evolutionary ecology studies. Anim Behav 70:967-971

Evans RD (2001) Physiological mechanisms influencing plant nitrogen isotope composition. Trends Plant Sci 6:121-126

Farquhar GD, Ehleringer JR, Hubick KT (1989) Carbon isotope discrimination and photosynthesis. Annu Rev Plant Phys Plant Mol Biol 40:503-537

Frei C (2007) The future climate of Switzerland. In: OcCC and ProClim (eds) Climate change and Switzerland 2050: expected impacts on environment, society and economy. OcCC and ProClim, Bern, pp 12-23

Green B, Tukey J (1960) Complex analyses of variance: general problems. Psychometrika 25:127-152

Hobbie EA, Colpaert JV (2003) Nitrogen availability and colonization by mycorrhizal fungi correlate with nitrogen isotope patterns in plants. New Phytol 157:115-126

Hobbie EA, Högberg P (2012) Nitrogen isotopes link mycorrhizal fungi and plants to nitrogen dynamics. New Phytol 196:367-382

Hobbie EA, Werner RA (2004) Bulk carbon isotope patterns in C3 and C4 plants: a review and synthesis. New Phytol 161:371-385

Högberg MN, Bååth E, Nordgren A, Arnebrant K, Högberg P (2007) Contrasting effects of nitrogen availability on plant carbon supply to mycorrhizal fungi and saprotrophs - a hypothesis based on field observations in boreal forest. New Phytol 160:225-238

Hultine KR, Marshall JD (2000) Altitude trends in conifer leaf morphology and stable carbon isotope composition. Oecologia 123:32-40

Jaatinen K, Fritze H, Laine J, Laiho R (2007) Effects of short- and long-term water-level drawdown on the populations and activity of aerobic decomposers in a boreal peatland. Glob Ch Biol 13:491-510

Klaus G (2007) État et évolution des marais en Suisse: résultats du suivi de la protection des marais. État de l'environnement 0730. Office fédéral de l'environnement, Berne

Körner C (1989) The nutritional status of plants from high altitudes. Oecologia 81:379-391

Körner C (2007) The use of "altitude" in ecological research. Trends Ecol Evol 22:569-574

Körner C, Farquhar GD, Roksandic Z (1988) A global survey of carbon isotope discrimination in plants from high-altitude. Oecologia 74:623-632

Körner C, Farquhar GD, Wong SC (1991) Carbon isotope discrimination by plants follows latitudinal and altitudinal trends. Oecologia 88:30-40

Marshall JD, Zhang J (1994) Carbon isotope discrimination and water se efficiency of native plants of the north-central Rockies. Ecology 75:1887-1895
Ménot G, Burns S (2001) Carbon isotopes in ombrogenic peat bog plants as climatic indicators: calibration from an altitudinal transect in Switzerland. Org Geochem 32:233-245

Nadelhoffer K, Shaver G, Fry B, Giblin A, Johnson L, McKane R (1996) ${ }^{15} \mathrm{~N}$ natural abundances and $\mathrm{N}$ use by tundra plants. Oecologia 107:386-394

Nilsson LO, Giesler R, Bååth E, Wallander H (2005) Growth and biomass of mycorrhizal mycelia in coniferous forests along short natural nutrient gradients. New Phytol 165:613-622

O'Leary MH (1981) Carbon isotope fractionation in plants. Phytochem 20:553-567

Pinheiro J, Bates D, DebRoy S, Sarkar D, the R Core Team (2014) nlme: linear and nonlinear mixed effects models. $\mathrm{R}$ package version $3.1-117$

R Core Team (2014) R: A language and environment for statistical computing. R Foundation for Statistical Computing, Vienna

Robinson D (2001) $\delta^{15} \mathrm{~N}$ as an integrator of the nitrogen cycle. Trends Ecol Evol 16:153-162

Terashima I, Masuzawa T, Ohba H, Yokoi Y (1995) Is photosynthesis suppressed at higher elevation due to low $\mathrm{CO}_{2}$ pressure? Ecology 76:2663-2668

Van der Heijden MGA, Martin FM, Sanders IR (2015) Tansley review mycorrhizal ecology and evolution: the past, the present, and the future. New Phytol 205:1406-1423

Van Heerwaarden LM, Toet S, Aerts R (2003) Nitrogen and phosphorus resorption efficiency and proficiency in six sub-arctic bog species after 4 years of nitrogen fertilization. $\mathrm{J}$ Ecol 91:1060-1070

Vergutz L, Manzoni S, Porporato A, Novais RF, Jackson RB (2012) Global resorption efficiencies and concentrations of carbon and nutrients in leaves of terrestrial plants. Ecol Monogr 82:205-220

Vitousek PM, Field CB, Matson PA (1990) Variation in foliar $\delta^{13} \mathrm{C}$ in Hawaiian Metrosideros polymorpha: a case of internal resistance? Oecologia 84:62-370

Wang B, Qiu YL (2006) Phylogenetic distribution and evolution of mycorrhizas in land plants. Mycorrhiza 16:299-363

Werner C, Gessler A (2011) Diel variations in the carbon isotope composition of respired $\mathrm{CO}_{2}$ and associated carbon sources: a review of dynamics and mechanisms. Biogeosciences 8:2437-2459

Westoby M, Wright IJ (2006) Land-plant ecology on the basis of functional traits. Trends Ecol Evol 21:261-268

Wright IJ, Reich PB, Cornelissen JHC, Falster DS, Garnier E, Hikosaka K, Lamont BB, Lee W, Oleksyn J, Osada N, Poorter H, Villar R, Warton DI, Westoby M (2005) Assessing the generality of global leaf trait relationships. New Phytol 166:485-496

Yano Y, Shaver GR, Giblin AE, Rastetter EB (2009) Depleted ${ }^{15} \mathrm{~N}$ in hydrolysable-N of arctic soils and its implication for mycorrhizal fungi-plant interaction. Biogeochemistry 97:183-194 